Short Paper

\title{
Analysis of the Population Structure of the Swimming Crab, Portunus trituberculatus in the Coastal Waters of Okayama Prefecture, by RFLPs in the Whole Region of Mitochondrial DNA
}

\author{
Hideyuki Imai, ${ }^{* 1, \dagger}$ Yoshihiro Fujii, ${ }^{* 2}$ Junichi Karakawa, ${ }^{* 3}$ \\ Shozo Yamamoto, ${ }^{* 3}$ and Ken-ichi Numachi*1 \\ ${ }^{*}$ Graduate School of Marine Science and Technology, Tokai University, \\ Orido, Shimizu, Shizuoka 424-8610, Japan \\ ${ }^{*}$ Okayama Prefectural Fisheries Experiment Station Sea Farming Center, \\ Ushimado, Oku, Okayama 701-4302, Japan \\ ${ }^{*}$ Okayama Prefectural Fisheries Experiment Station, Ushimado, Oku, \\ Okayama 701-4302, Japan
}

(Received August 11, 1998)

Key words: Portunus trituberculatus, mitochondrial DNA, RFLP, genetic diversity, population
genetic structure

The swimming crab Portunus trituberculatus is widely distributed in the coastal waters of Japan. This species is of commercial importance in the coastal fisheries of Japan, yielding about 4,150 tons per year." Artificial propagation and stocking of this species began in 1960 under the auspices of the Ministry of Agriculture and Fisheries. The population structure of the swimming crab has been investigated previously by allozyme analysis. ${ }^{27}$ Recently, analysis of restriction fragment length polymorphisms (RFLPs) of the whole region ${ }^{3)}$ and the D-loop region ${ }^{4)}$ of mitochondrial DNA (mtDNA) were performed to clarify the genetic variability and population structure. However, intra- and inter-populational variability, success and the effects of stocking on the genetic composition of native populations have not yet been addressed.

In the present study, the genetic variability of the swimming crab at four sampling sites in Okayama Prefecture was studied using RFLPs analysis of the whole region of mtDNA.

In 1997, 511 individuals were collected by trawl fishing or gill net at four locations in Okayama Prefecture, Japan. The four sampling sites are Mizushima-Nada, HarimaNada Northwest, Ushimado Town and Hinase Town (Fig. 1). These sites are located within about 100 kilometers of each other. The 4 th legs from each specimen were frozen and shipped at $-20^{\circ} \mathrm{C}$ for the test.

Total crude DNA was extracted by the method described previously. ${ }^{3)}$ The endonucleases, Hinc II, Hpa I and Stu I (Takara Shuzo Co., Japan) were selected for this study based on the results of a preliminary test showing polymorphisms in restricted fragment sizes. Polymorphisms were identified by agarose gel electrophoresis of the cleared mtDNA fragments. Electrophoretic patterns were visualized by southern blotting followed by DNA hybridization with digoxigenin labeled mtDNA of the swimming crab. ${ }^{3)}$ Mitochondrial DNA used as the probe was purified from a fresh, immature ovary of the swimming crab by $\mathrm{CsCl}$-ethidium bromide density gradient ultracentrifugation. ${ }^{3)}$ Restriction patterns observed in each endonuclease digestion were alphabetically labeled and composited for comparing haplotype frequencies between the population samples. The nucleotide diversity ${ }^{5)}$ and haplotypic diversity ${ }^{5,6)}$ were calculated from the presence/ absence matrix of restriction sites in each endonuclease and frequency of each haplotype. The distribution of haplotypes between population samples was evaluated for homogeneity using the chi-square randomization method (Monte Carlo simulation) ${ }^{7)}$ with 10,000 randomizations of the data.

RFLPs profiles observed by each of the three endonucleases are shown in Table 1. Six RFLPs patterns were observed in HincII, four patterns in $H p a \mathrm{I}$, and four patterns in StuI. The size of mtDNA in the swimming crab was estimated to be $15,961 \pm 290$ base pairs. Sixteen haplotypes were identified in the 511 individuals analyzed (Table 2). Haplotypes 1 to 3 were found in high frequencies in all the samples analyzed.

Genetic variability within the population samples was examined by the haplotypic diversity (Table 2) and nucleotide diversity (Table 3). Both estimates of genetic diversity indicate that all of the population samples analyzed have the same level of genetic variability.

We examined the degree of variability among the population samples. Estimates of nucleotide divergence among the population samples are shown in Table 3. The values were similar among all the combinations, ranging from 0.34 to $0.39 \%$. However, as shown in Table 4, a significant level of heterogeneity was found between the population samples from Mizushima-Nada and those from Hinase Town $(p<0.05)$. Significant heterogeneity was also observed between the Mizushima-Nada and the other three popula-

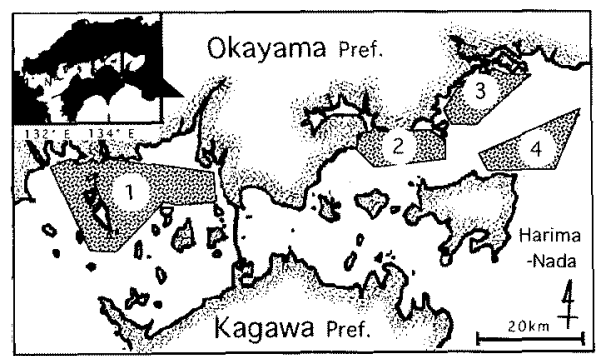

Fig. 1. Location of sampling sites.

1: Mizushima-Nada ( $n=287$ : avg. long carapace width (LCW) $=184.9 \mathrm{~mm}) .2$ : Ushimado Town $(n=77: \mathrm{LCW}=217.3 \mathrm{~mm}) .3$ : Hinase Town $(n=101: \mathrm{LCW}=142.4 \mathrm{~mm}) .4$ : Harima-Nada Northwest $(n=46: \mathrm{LCW}=153.1 \mathrm{~mm})$.

\footnotetext{
† Present address: Hideyuki Imai, Ph.D., Department of Fisheries, Faculty of Marine Science and Technology, Tokai University, 3-20-1 Orido, Shimizu 424-8610, Japan. Fax: +81(543)-34-9764 (To whom correspondence should be addressd.)
} 
Table 1. Fragment size estimates (in base pairs) for three endonucleases that produced polymorphic restriction patterns in swimming crab mitochondrial DNA

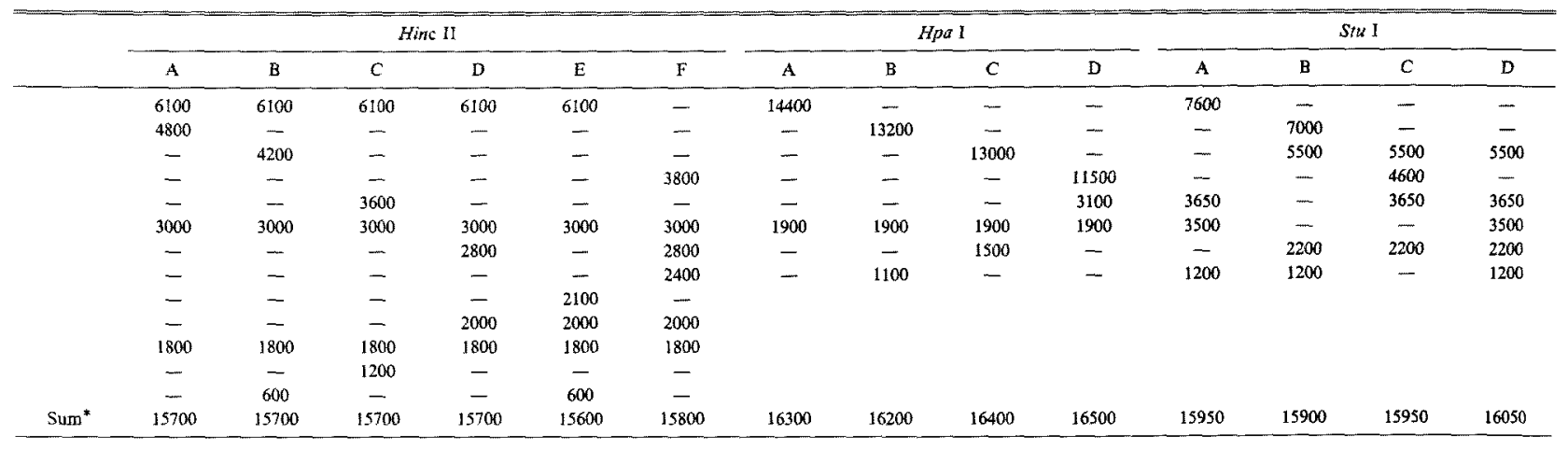

Table 2. Distribution of mtDNA haplotypes and haplotypic diversity of the swimming crabs sampled from Okayama Prefecture

\begin{tabular}{|c|c|c|c|c|c|c|c|c|}
\hline \multirow{2}{*}{ Haplotype } & \multicolumn{3}{|c|}{ Restriction morph } & \multirow{2}{*}{ Mizushima-Nada } & \multirow{2}{*}{$\begin{array}{l}\text { Ushimado } \\
\text { Town }\end{array}$} & \multirow{2}{*}{$\begin{array}{l}\text { Hinase } \\
\text { Town }\end{array}$} & \multirow{2}{*}{$\begin{array}{c}\text { Harima-Nada } \\
\text { Northwest }\end{array}$} & \multirow{2}{*}{ Total } \\
\hline & Hinc II & Hpa 1 & Stu I & & & & & \\
\hline 1 & D & A & D & 140 & 33 & 36 & 19 & 228 \\
\hline 2 & D & D & D & 75 & 28 & 26 & 12 & 141 \\
\hline 3 & A & $\mathrm{A}$ & D & 52 & 10 & 28 & 12 & 102 \\
\hline 4 & D & A & $\mathrm{C}$ & 3 & 0 & 0 & 0 & 3 \\
\hline 5 & D & A & A & 4 & 1 & 5 & 0 & 10 \\
\hline 5 & $\mathrm{E}$ & A & D & 6 & 0 & 1 & 0 & 7 \\
\hline 7 & D & D & A & 1 & 2 & 1 & 0 & 4 \\
\hline 8 & B & A & $\mathrm{D}$ & 2 & 0 & 0 & 0 & 2 \\
\hline 9 & $D$ & $A$ & B & 1 & 2 & 1 & 0 & 4 \\
\hline 10 & $\mathrm{C}$ & $\mathrm{C}$ & D & 1 & 0 & 0 & 0 & 1 \\
\hline 11 & D & $\mathrm{c}$ & $\mathrm{D}$ & 1 & 0 & 0 & 0 & 1 \\
\hline 12 & A & A & A & 1 & 0 & 0 & 0 & 1 \\
\hline 13 & $\mathrm{E}$ & B & D & 0 & 0 & 1 & 1 & 2 \\
\hline 14 & B & B & D & 0 & 0 & 2 & 1 & 3 \\
\hline 15 & F & A & D & 0 & 0 & 0 & 1 & $i$ \\
\hline 16 & C & B & $\mathrm{D}$ & 0 & 1 & 0 & 0 & 1 \\
\hline \multicolumn{2}{|c|}{ Number of haplotypes } & & & 12 & 7 & 9 & 6 & 16 \\
\hline \multicolumn{2}{|c|}{ Total no. of specimens } & & & 287 & 77 & 101 & 46 & 511 \\
\hline \multicolumn{2}{|c|}{ Haplotypic diversity } & & & 0.622 & 0.674 & 0.734 & 0.707 & $0.694^{*}$ \\
\hline
\end{tabular}

"Average of haplotypic diversity.

Table 3. Estimates of nucleotide divergence of the swimming crab

\begin{tabular}{lcccc}
\hline & $\begin{array}{c}\text { Mizushima- } \\
\text { Nada }\end{array}$ & $\begin{array}{c}\text { Ushimado } \\
\text { Town }\end{array}$ & $\begin{array}{c}\text { Hinase } \\
\text { Town }\end{array}$ & $\begin{array}{c}\text { Karima- } \\
\text { Nada } \\
\text { Northwest }\end{array}$ \\
\hline $\begin{array}{llcl}\text { Mizushima-Nada } \\
\text { Ushimado Town }\end{array}$ & 0.0032 & 0.0034 & 0.0037 & 0.0035 \\
Hinase Town & & 0.0034 & 0.0039 & 0.0038 \\
Harima-Nada & & & 0.0041 & 0.0038 \\
Northwest & & & & 0.0038
\end{tabular}

Above the diagonal: besween population samples.

Diagonal: within population samples.

tion samples, pooled $(p<0.01)$. Thus, the population at Mizushima-Nada could be distinguished from the populations at the other three locations by haplotype frequency.

In previous reports based on allozyme research, it has been proposed that the swimming $\mathrm{crab}^{2)}$ and the blue $\mathrm{crab}^{8)}$ have panmixial population structures throughout their wide distribution ranges. The present data suggests populations of the swimming crab are genetically heterogenous even in a small area such as the coastal waters of Okayama Prefecture.

We wish to thank Mr. H. Hashimoto and Mr. M. Hata for their technical assistance. We are grateful to Dr. Takashi Matsuishi of Hokkaido University for providing a computer program (ROFF. EXE). We are also grateful to the staff of the Okayama Prefectural Fisheries Experimental Station, and the Okayama Prefectural Sea Farming Center for kindly providing the experimental materials.

\section{References}

1) Ministry of Agriculture and Fisheries, Statistics and Information
Table 4. Pairwise haplotype frequency comparisons based on chisquare randomization test, using the Monte Carlo simulation method

\begin{tabular}{lcccc}
\hline & $\begin{array}{c}\text { Mizushima- } \\
\text { Nada }\end{array}$ & $\begin{array}{c}\text { Ushimado } \\
\text { Town }\end{array}$ & $\begin{array}{c}\text { Hinase } \\
\text { Town }\end{array}$ & $\begin{array}{c}\text { Harima- } \\
\text { Nada } \\
\text { Northwest }\end{array}$ \\
\hline Mizushima-Nada & 0.100 & $0.027^{*}$ & 0.088 \\
Ushimado Town & $(0.003)$ & $(0.002)$ & $(0.003)$ \\
Hinase Town & 0.067 & 0.119 \\
Harima-Nada & & $(0.002)$ & $(0.003)$ \\
Northwest & $(0.001)$ & & 0.783 \\
& & & \\
\hline
\end{tabular}

Numerals shown above and below the diagonal: $p$-yatues between each set of localities were calculated with 10,000 replications.

Below the diagonal: between the Mizushirta-Nada and the other three population samples (pooled). The standard errors shown in parentheses were obtained by the Monte Carlo simulation method of Roff and Bentzen (1989).

* Significant level al $P<0.05$.

". Significant level at $P<0.01$.

Department: Agriculture Statistics Association, Tokyo, 1997, pp. 89.

2) N. Taniguchi and H. S. Han: Populational Studies of Fish and Shellfish by Isozymes Analysis, Japan Fisheries Resource Conservation Association, Tokyo, 1989, pp. 295-300.

3) H. Imai and K. Numachi: Bull. Inst. Oceanic Res. \& Develop., Tokai Univ., 19, 33-39 (1998).

4) H. Imai and K. Numachi: Bull. Inst. Oceanic Res. \& Develop., Tokai Univ., 19, 41-46 (1998).

5) M. Nei: Molecular Evolutionary Genetics (Translated from English by T. Gojyobori and N. Saito), Baifukan, Tokyo, 1990, pp. 218228.

6) M. Nei and F. Tajima: Genetics, 97, 145-163 (1981).

7) D. A. Roff and P. Bentzen: Mol. Biol. Evol, 6, 539-545 (1989).

8) A. L. McMillen-Jackson, T. M. Bert and P. Steele: Mar. Biol., 118, 53-65 (1994). 